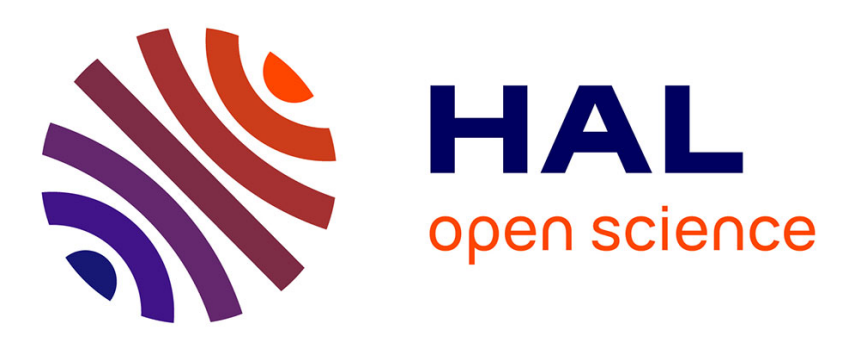

\title{
Disabled sportswomen and gender construction in powerchair football
}

Rémi Richard, Hélène Joncheray, Eric Dugas

\section{To cite this version:}

Rémi Richard, Hélène Joncheray, Eric Dugas. Disabled sportswomen and gender construction in powerchair football. International Review for the Sociology of Sport, 2015, pp.1 - 21. $10.1080 / 09687590500086492$. hal-01563257

\section{HAL Id: hal-01563257 \\ https://hal-insep.archives-ouvertes.fr/hal-01563257}

Submitted on 18 Jul 2017

HAL is a multi-disciplinary open access archive for the deposit and dissemination of scientific research documents, whether they are published or not. The documents may come from teaching and research institutions in France or abroad, or from public or private research centers.
L'archive ouverte pluridisciplinaire HAL, est destinée au dépôt et à la diffusion de documents scientifiques de niveau recherche, publiés ou non, émanant des établissements d'enseignement et de recherche français ou étrangers, des laboratoires publics ou privés. 


\title{
Disabled sportswomen and gender construction in powerchair football
}

\author{
Rémi Richard and Helene Joncheray
}

Université Paris Descartes - Sorbonne Paris Cité, France

\section{Eric Dugas}

Université Montesquieu Bordeaux IV, France

\begin{abstract}
Sports and physical activities are ideal fields to study gender construction. Much research aims at shedding light on these processes. Women involved in 'male' sports have been extensively studied, and mixed-sex activities have sometimes been used to support these studies, but research has rarely focused on populations of disabled athletes. Yet, the phenomenon of gender construction takes on a particular meaning in the context of disability, insofar as the relations between sports, gender and disability raise the issues of production and negotiation of bodily norms in a specific way. We will try to understand this gender construction phenomenon through the study of ten French powerchair football players, with whom we conducted a participant observation over two and a half years, as well as in-depth interviews. We will pay particular attention to the case of three sportswomen who competed in an almost exclusively male champion ship. We will see that these women are confronted with a dilemma: going against the stereotype of the asexual Paralympian female athlete while performing masculinity to gain legitimacy in a men's world. These sportswomen thus 'play the game' of masculinity through a set of discursive, behavioral and clothing strategies in order to find a place in powerchair football, while still preserving some of their 'femininity.'
\end{abstract}

\section{Keywords}

disability, gender, identity, powerchair football, sportswomen

\section{Introduction}

Football in an electric wheelchair, also called powerchair football or power soccer, is not a well-known sport among the general public, and yet is very popular in the world of

\footnotetext{
Corresponding author:

Rémi Richard,UFR STAPS, Université Paris Descartes - Sorbonne Paris Cité, I rue Lacretelle, 75015 Paris, France.

Email: richardremi@hotmail.fr
} 
disabled sports, as shown by the last World Cup held in Paris in 2011, during which 80 international players met in front of more than 3000 spectators (Handisport, 2012). It is the only team sport that can be played by individuals using an electric wheelchair on a daily basis. This sport was formally recognized in France in the early 1980s (Richard, 2014a) and expanded quickly on the national, then international levels (Richard, 2014a). Its emergence coincided with the development of powerchairs and was originally linked with therapeutic purposes (Ruffié and Ferez, 2013; Watson and Woods, 2008). Indeed, this activity was offered by physiotherapists or educators working at rehabilitation centers to introduce electric wheelchairs to disabled children in a playful way.

Today, powerchair football is played in gymnasiums on regulation basketball courts, with two opposing teams of four players (including a goalkeeper) using powerchairs that are equipped with footguards. As in football, the aim is to take the ball, which is oversized, to the opposing team's goal and to score more goals than the opponent team. On the field, teams are mixed and there are no exclusively male or exclusively female championships. Powerchair football is an established sports activity, structured through rules and an institution, the FIPFA (Fédération Internationale de Powerchair Football Association). At the international scale, FIPFA had 3500 registered players in 2014. The main national federations affiliated to FIPFA are England (900 affiliated members), France (625), ${ }^{1}$ the United States (600) and Japan (550). ${ }^{2}$ The actual number of persons playing powerchair football is difficult to establish, precisely because not all of them are affiliated to FIPFA. With more than 600 players registered for competition with the FFH (Fédération Française Handisport) and an estimated 450 recreational, unaffiliated players, powerchair football is the second largest competitive team sport for disabled people in France. Among the 625 French competitive players, 80 (or 12.7\%) are women and 10 of them play in the French championship's top two leagues. ${ }^{3}$

Powerchair football is a team sports activity directed at a population that is usually excluded or rarely considered as sporty. Participants include people with cerebral palsy, muscular dystrophy, spinal cord injury, arthrogryposis or any other pathology that can lead to partial or total quadriplegia.

Powerchair football is thus the only team sport that can be played by electric wheelchair users and the only one to propose mixed matches. Our research is based upon the experience of these players using a powerchair in a mixed sport. This practice leads us to question gender construction vis-à-vis disabilities. It is a good place to see this important process at work.

In order to understand these processes, we chose to anchor our approach in a pragmatic perspective, more particularly the Chicago School's. The Goffmanian framework, which combines in-depth interviews with direct observations, permits to grasp the way gender is constructed, not only in view of the players' past experience but also of their 'in vivo' practice. We thus looked into the gender construction and negotiation processes within two French powerchair football clubs. Our study will bear both on the gender strategies female powerchair football players put in place, and on male players' opinion in this particularly masculine world. ${ }^{4}$

From a theoretical point of view, we will draw on the framework of gender studies and of disability studies that seek to highlight the social processes of gender (Butler,1999; Mead, 1963; Oakley, 1972) and disability construction (Oliver, 1990, 2013; Shakespeare 
and Watson, 2001; Sherry, 2014). Our work is thus in line with the existing literature in the fields of disabled sport and gender. These gender and disability construction mechanisms are particular in sports, where physical involvement seems to 'naturalize' individuals' differences and tastes depending on their gender (Connell, 2000). Sports bringing physical force and confrontation into play would thus be masculine, as opposed to morphokinetic activities. 'Able-bodied' football truly constitutes a bastion of masculinity in Europe (Anderson, 2009; Lajeunesse, 2008). However, there is a major difference between these two sports: 'able-bodied' football is played with teams of the same gender, whereas the disabled version allows for mixed-sex matches. We wish to examine these disabled athletes' identity constructions in this mixed confrontation context.

\section{Theoretical framework}

Our research work is at the interface of two different issues. The first is the gender identity production process in sports; the second is the masculinity and femininity of the 'disabled' body. Our goal is to identify gender production mechanisms at work in powerchair football.

\section{Gender social construction}

Not until the 20th century did we stop thinking of differences between men and women as biological, 'natural' products. In 1949, Simone De Beauvoir was the first French person to call into question this biological essentialism (De Beauvoir, 1949). Gender then started being perceived by human and social sciences as the result of social processes. Twenty years later, Oakley (1972) differentiated the notions of sex and gender, the latter referring to socially constructed masculinities and femininities. For Bourdieu (2001), driving force of gender production is socialization. According to him, gendered socialization consists in a physical and psychological incorporation of gender norms. Bourdieu speaks of a 'psychosomatic work which, when applied to boys, aims to virilize them by stripping them of everything female which may remain in them' (Bourdieu, 2001: 27). This virilization or feminization work is based on a form of masculine domination and gives it an apparent biological legitimacy: 'The masculinization of the male body and the feminization of the female body [...] induce a somatization of the relation of domination, which is thus naturalized' (Bourdieu, 2001: 55-56). Yet, gender norms are not set in stone. As Hargreaves explains, 'the masculine domination and other forms of domination are partial (...) the agency (freedom) and determinism (constraints) are in dialectical relation' (Hargreaves, 2006: 112). This way, gender norms and domination relations will be addressed, negotiated in everyday practice. It is also the opinion of Goffman, for whom an individual's behavior is neither completely free nor completely predetermined. It consists above all in a 'fuzzy coupling between the interactions' order and the structure' (Goffman, 1988: 217). In this context, the individual turns into an actor: Goffman uses theatrical imagery to highlight the social experiences of everyday life complexity and instability. Playing with norms, the individual caught in the interaction participates in the construction of reality (Berger and Luckmann, 1966). When he transposes this theoretical framework to gender analysis, Goffman shows that face-to-face interaction is 
a moment of gender norm construction. Gender is then a 'part' the individual plays, that 'naturalize' behaviors specific to each gender. This is what Goffman (1977b) calls 'institutional reflexivity.' As noted by Azadeh (2010), 'the analysis of social interaction as a theatrical performance by Goffman has made it possible to think of the gender's performativity which was theorized by Butler three decades later' (Azadeh, 2010: 278). Butler did apply herself to deconstructing the idea according to which gender constitutes a stable identity: 'gender is always a doing, though not a doing by a subject who might be said to preexist the deed' (Butler, 1999: 33). Individuals are thus at the heart of the gender construction process. The abiding gendered self is structured (or deconstructed) on a daily basis, 'by repeated acts that seek to approximate the ideal of a substantial ground of identity' (Butler, 1999: 179). At this level, Butler's approach differs from that of Goffman, who considers the 'self' as an 'interior space':

As opposed to a view such as Erving Goffman's which posits a self which assumes and exchanges various 'roles' within the complex social expectations of the 'game' of modern life, I am suggesting that this self is not only irretrievably 'outside,' constituted in social discourse, but that the ascription of interiority is itself a publically regulated and sanctioned form of essence fabrication. (Butler, 1988: 524)

By making these proposals, Butler threatened the stability of gender norms, and more generally of corporal norms. These proposals resonate in disability studies if discourses and acts are involved in the construction and deconstruction of masculine and feminine bodies, and it is the same for the production of 'able' or 'disabled' bodies (Hodkings and Baility, 2009). Zitzelsberger notes that 'constructions of disability/ability and abnormal/ normal in hegemonic discourses intermesh with other discourses, including gender' (Zitzelsberger, 2005: 390). Just as the heterosexual dogma system constructs the man/ woman binarism (Wittig, 1978), 'ableism' constructs the able/disabled difference (McRuer, 2006; Kumari Campbell, 2009). Gender studies and disability studies both question binary oppositions by underlining the contemporary individual's multifaceted, intercultural identity (Korff-Sausse, 2011). Like the 'queer' identity, the 'disabled' identity emerges from an experience of oppression and from social discrimination (Inckle, 2014; Kafer, 2003; McRuer, 2006; Sherry, 2004).

\section{Gender, disability and physical activity}

A disabled person's gender identity has seldom been dealt with and there is a lack of literature about this issue. Ancet (2010) explains this by the fact that the sexuality and the sexual identity of disabled people have long been unthinkable. He finds that disabled people are often 'placed in an intermediate status between children and adults, as if they were expected to recognize their inability to have a sexuality' (Ancet, 2010: 41). In this case, since disabled people's bodies are seen as asexual they are, indeed, seen as nongendered: 'Discourses of women with disabilities as non-gendered, nonsexual, childlike and dependent extend to assumptions regarding women being unable to be sexual, spouses, partners or mothers. Noticeable body differences cause confusion and comment' (Zitzelsberger, 2005: 395-396). The same applies to men who would be 'placed in 
the position of neutralized men. Not non sexed, but emasculated by their supposed weakness' (Ancet, 2010: 42).

Like Porter (1997), Dufour (2014) noted that sports constitute a discriminatory space for men who cannot 'play the sports prized by bipedal masculinity' (Dufour, 2014). Because sports activities, competitive ones in particular, create an 'hegemonic motor ability' (Dufour, 2014), disabled people are often discredited from the start.

When a handicapped man starts entering the competition field with able-bodied men, he finds himself referred to his disability much more frequently. As if bringing him down to his physical appearance, to his motor skills and returning to the comfort of stereotype could make sure that he does not enter the field of rivalry. (Ancet, 2010: 41).=

Yet, disabled people have gotten involved in the sports movement (Brittain, 2008; Gilbert and Schantz, 2008; Guttmann, 1976; Marcellini, 2005). Sports activities for disabled people are actually becoming mainstream and reaching a bigger and bigger audience (Richard, 2014b). Consequently, the issue of gender construction in disabled sports has been raised (DePauw, 1999). The pioneering study of Blinde and McCallister (1999), as well as Hardin's (2007) more recent work, show that sport is often used by disabled women as a way to 'move them away from the stigma' of disability (Hardin, 2007: 45). Echoing the observations made by Zitzelsberger (2005), Schell and Rodriguez (2001) noticed that disabled sportswomen undergo an examination of their feminine identity. In their article about the media coverage of wheelchair tennis player Hope Lewellen, Schell and Rodriguez (2001) claim that she is depicted as asexual and non-gendered. The analytical work of Apelmo (2012a) on the discourse of the Swedish Sports Organization for the Disabled (S.H.I.F.) reinforces these observations. It shows how disabled people, female athletes in particular, are portrayed within the Paralympic movement. 'By not mentioning gender [...] the S.H.I.F. also contributes to a discourse that regards disabled people as ungendered and to the further exclusions of disabled women from sports' (Apelmo, 2012a). In 'able-bodied' sports, women have to stage their femininity in order to assert their athleticism and thus avoid stigmatization (Bohuon, 2008; Joncheray et al., 2014; Mennesson, 2005). In the sphere of disabled sports, research shows that journalists and even institutions evade women's femininity, which leads to the exclusion of female athletes (Apelmo, 2012b). The analysis of the interviews Apelmo carried out with 12 hockey players shows that they must face a contradiction: opposing a dominant discourse in sport that requires athletes to be feminine, and in parallel facing another discourse that presents disabled women as asexual: 'Challenge the gender discourse within sports by displaying toughness, strength and risk-taking, while constructing a more traditional femininity against the view of disabled women as nongendered and asexual' (Apelmo, 2012b: 406).

Technology, the wheelchair in particular, plays a crucial role in these contradictions, as illustrated by the way Maria describes hers:

Maria illustrates the link between sports equipment and assistive technology by characterizing her wheelchair as sporty, thus relocating it from one field to another. She also shifts her wheelchair from a masculine discourse of technology to a feminine discourse of accessories, 
when talking about it as 'tremendously fine,' 'really gorgeous' and 'sporty in a pretty way.' Such talk is a way for her to construct femininity despite sitting in a masculinely coded wheelchair. (Apelmo, 2012b: 405)

For these disabled sportswomen, it thus seems necessary to redouble their efforts in order to put in play a sort of femininity that calls into question the image of the 'asexual' athlete while resisting the stigmas imposed upon them by the discourses about women in the sports sphere (Blinde and McCallister, 1999). Powerchair football players do not escape these injunctions. However, they evolve in a masculine environment, filled with masculine norms. They must then tackle a paradox: staging a sporty femininity, but without losing their legitimacy in a masculine world (Joncheray et al., 2014; Messner, 2007).

Disabled women's relation to femininity is not uniform. It is directly influenced by their disability's nature and its innate character or not (Hardin (2007). Our study is an opportunity to analyze gender identity from the point of view of these women 'in electric wheelchair', 'severely disabled', those whose bodies are not 'legitimate' (Prude and Howe, 2013) in the eyes of the general public. Because technology plays an important role in powerchair football and its use has a direct impact on gender construction. For Haraway (1991) the cyborg body, as a 'cybernetic organism, a hybrid of machine and organism' (Haraway, 1991: 149), dissolves the barriers between nature and culture, and calls into question the duality of gender (Haraway, 1991:178).

Powerchair football players foster an intimate connection with technology (Richard, 2012). Hybridization (Andrieu, 2008) with the chair questions the body's material limits and challenges the 'biological inequalities' which make this sport a showcase of gender binarity. In this regard, the study of powerchair football makes it possible to take a look at these 'hybrid players' gender production in the context of mixed confrontation.

\section{Questions}

Numerous studies have been devoted to the place of women in a particularly 'masculine' sport environment (Groenen, 2005; Joncheray et al., 2014; Louveau, 1986; Mennesson, 2005; Mercier-Lefèvre, 2005). The issue of masculinity production in and through sports gets more and more attention (Duret, 2009; McKay and Laberge, 2006; Wenner and Jackson, 2009). More rarely, gender construction is carried out within a mixed-sex activity, in which men and women interact (Guérandel and Mennesson, 2007; Hargreaves, 1992; Richard and Dugas, 2012). And yet that is the case in powerchair football, with its mixed matches. Gender construction phenomena in powerchair football are all the more unusual as the motor deficit changes the way gender is perceived (Hendey and Pascall, 1998; Apelmo, 2012a). We will examine the numerous and paradoxical gender injunctions disabled sportswomen are submitted to (Guthrie and Castelnuovo, 2001) and try to understand how the mixed nature of powerchair football affects gender production mechanisms. Moreover, since powerchair football is one of very few sports for people in electric wheelchairs, we will try to determine how the use of these chairs can constitute an opportunity to 'undo' gender. The aim of the present article is twofold: first to highlight how gender norms are constructed in powerchair football, and then to understand the strategies adopted by female athletes to 
build their identity as disabled sportswomen. This analysis will made be possible by paying particular attention to the way male players $(87.3 \%$ of the French players registered for competition $)^{5}$ view women's participation.

\section{Methodology}

Powerchair football is a sporting phenomenon which is interesting when trying to understand gender identity construction. In order to highlight these mechanisms, we chose to embrace a pragmatic methodology, namely the Goffmanian paradigm. We wanted to understand how gender norms are negotiated in the powerchair football situation. Goffman (1975, 1977a) insists on the actors' role in the social production of reality: it is in the daily interactions that individuals construct 'their reality'. The qualitative study of interactions is an approach that is particularly adapted to our fieldwork, which is made up of two powerchair football clubs (A and B) totaling 15 players and two coaches. The clubs around Paris (France) usually have eight to ten players separated into two teams. The particularity of Club B is that it has three of the 10 women who play in the French championship's top two leagues, the other seven playing each for a different club. This group of athletes is aged between 19 and 38. All players, except one from club B, have been disabled from birth. They play powerchair football competitively in first or second division, and contrary to the basketball players interviewed by Hardin (2007), they all use electric wheelchairs.

Over the course of three years (or 157 weeks), between 2010 and 2013, we took part in the lives of the two clubs both during training sessions $(n=96)$ and competitions $(n=8)$. During this phase, we minutely noted all our observations in a fieldwork notebook (Patton, 2002). We also wrote down the speeches we witnessed or the informal discussions we had with the protagonists. In addition to this participant observation, we carried out 13 in-depth interviews, lasting two hours on average, with eleven players including two women (the third woman was 'observed' but could not be interviewed for health reasons) and the two coaches of each club. This sample is made up of assiduous players, meaning they come to practice and take part in competitions on a regular basis. We also interviewed 'privileged witnesses', whom we had chosen using the 'network sampling' method (Patton, 2012). These privileged witnesses are physical therapists $(n=2)$, carers $(n=5)$ and the FIPFA's president.

The interviews were recorded, with the athletes' consent, then completely transcribed. They made it possible to trace the life path and sports career of our interlocutors and gradually tackle the issue of masculinity and femininity in powerchair football. We carried out a thematization work (Glesne, 2011) to process the data. A first reading allowed us to draw the main ideas (Strauss and Corbin, 1990) emerging from the verbatim corpus. We carried out a second and a third reading in order to isolate themes identified thanks to the recurrence of their apparitions in the interviews. During the second reading, we isolated three 'primary patterns' for the analysis (Sandelowski, 2000): gender construction and deconstruction strategies; the particularity of mixed confrontations vis-àvis gender (de)construction; integration difficulties in a particularly masculine environment. The third reading allowed us to refine the primary patterns by drawing to the surface subcategories (Highlen and Finley, 1996). During this reading, the first 
Table I. Interviewees table.

\begin{tabular}{|c|c|c|c|}
\hline $\begin{array}{l}\text { Name/gender } \\
\text { Club }\end{array}$ & Parcours & Age & Motor deficit \\
\hline Abdel & Discovered PF at the age of 13. & 35 & Brittle bone disease \\
\hline male & Works for a sports club. & & \\
\hline Club A & Married with two kids. & & \\
\hline Salim & Discovered PF at the age of 13 . & 28 & Brittle bone disease \\
\hline male & Unemployed. & & \\
\hline Club A & Bachelor. & & \\
\hline Timothée & Discovered PF at the age of 10 . & 12 & $\begin{array}{l}\text { Infantile spinal } \\
\text { muscular atrophy }\end{array}$ \\
\hline male & Still goes to school. & & Tracheostomized \\
\hline \multicolumn{4}{|l|}{ Club A } \\
\hline Romain & Discovered PF at the age of 16 . & 32 & $\begin{array}{l}\text { Paraplegia of non- } \\
\text { specified origin }\end{array}$ \\
\hline male & Former player, put an end to his career. & & \\
\hline Club B & $\begin{array}{l}\text { Employed by the Fédération Française } \\
\text { Handisport. }\end{array}$ & & \\
\hline Aymeric & Discovered PF at the age of 10 . & 26 & Cerebral palsy \\
\hline male & Bachelor, lives in a group home. & & Speech impairment \\
\hline Club A & Unemployed. & & \\
\hline Loïc & Discovered PF at the age of 9. & 23 & $\begin{array}{l}\text { Infantile spinal } \\
\text { muscular atrophy }\end{array}$ \\
\hline Male & $\begin{array}{l}\text { Lives with a partner, in a housing unit } \\
\text { for disabled tenants. }\end{array}$ & & Tracheostomized \\
\hline Club B & Unemployed. & & \\
\hline Damien & Discovered PF at the age of 13 . & 35 & Cerebral palsy \\
\hline Club B & $\begin{array}{l}\text { Lives with his mother. } \\
\text { Unemployed. }\end{array}$ & & Speech impairment \\
\hline Amélie & Discovered PF at the age of 14 . & 30 & Myopathy \\
\hline female & Lives on her own in a group home. & & \\
\hline Club B & Unemployed. & & \\
\hline Sonia & Discovered PF at the age of 17 . & 32 & Myopathy \\
\hline female & Lives with a partner. & & \\
\hline Club B & Unemployed. & & \\
\hline Benoît & Discovered PF at the age of 16 . & 38 & $\begin{array}{l}\text { Particularly spastic } \\
\text { cerebral palsy }\end{array}$ \\
\hline male & Lives with his parents. & & Speech impairment \\
\hline Club B & Unemployed. & & \\
\hline Alexandre & Diagnosed at the age of 7 . & 34 & $\begin{array}{l}\text { Becker muscular } \\
\text { dystrophy }\end{array}$ \\
\hline Male & $\begin{array}{l}\text { Started using a powered wheelchair at } \\
\text { the age of } 30 \text {. }\end{array}$ & & \\
\hline \multirow[t]{2}{*}{ Club B } & $\begin{array}{l}\text { Discovered PF at the age of } 32 \text {. } \\
\text { Engineer. }\end{array}$ & & \\
\hline & Married with two kids. & & \\
\hline
\end{tabular}

PF: powerchair football 
pattern brought out two important paradoxical orientations in the gender production strategies: performing both 'masculinity' in order to gain legitimacy, but also femininity. The analysis of the second pattern brings to light a possible deconstruction of gender stereotypes through the use of chairs in the context of mixed confrontations, a deconstruction which is still relativized by the players who, from what they say, seem to 'renaturalize' female players' 'behaviors'. Lastly, the third pattern brings out the sexism which characterizes powerchair football (in particular at a high level) and the grouping strategies adopted by female players in order to create a fair environment. The anonymity of the respondents was guaranteed, since we changed their names.

\section{Results and discussion}

\section{The gender construction processes}

The studies we previously mentioned underline how complicated it is to be a disabled sportswoman, especially so for women playing powerchair football because they have to battle yet another element, i.e. the fact that they are in to a mostly masculine environment. Day in day out, they have to cooperate with and physically oppose men. And to find a place in this men's world, they will be faced with a dilemma: performing a form of masculinity to gain recognition in this male environment without sacrificing their femininity.

Displaying masculinity on and off the field to get away from the cliché of the unathletic woman. The three women from Club B we followed play at the French league's highest level. They compete easily with the best male players of the French championship. Despite these capabilities, they claim it is not easy to gain legitimacy in the male-dominated world of powerchair football, especially at a high-level. As shown by Hardin and Hardin (2005), disabled sportswomen are often presented in a stereotypical way and femininity is discredited in 'masculine' sports (Hargreaves and Hardin, 2009; Lindemann and Cherney, 2008; Lindemann, 2010). According to these players, the difficulty lies in the appropriation of some 'masculine' norms specific to team sports (Louveau, 1986; Mennesson, 2005; Pike, 2007) while expressing their femininity.

One of the first strategies chosen by the players in order to be in line with the masculinity prevailing in sport is to use speech. It consists in reaffirming the stereotypical attitudes and behaviors of women, and criticizing them strongly to distinguish themselves from them. For example, Sonia described to us the 'classic' woman as being delicate, precious and particularly concerned about her appearance and 'naturally' prone to jealousy or gossip. Then she hastened to add that 'she does not understand' and does not agree with these attitudes, positioning herself away from the female stereotypes she had constructed.

This discursive strategy seems to be a way to distance oneself from a femininity considered as incompatible with powerchair football. But the three players go even further in order to carve out a place in this male world. For them, it is indeed necessary to adopt behaviors on the field that are considered typical of a 'masculine' game: power, speed, sometimes even brutality (Lindemann, 2010; Messner, 1990). Celine explained during a 
training session that from the beginning, she felt the need to 'overplay' a masculinity to gain some form of respect:

In my first matches, I was a little bit of a bully.... Just to say: 'OK, I may be a girl but I get out there and do what's got to be done.' I even did a little too much, so I calmed down afterwards (laughs). Celine, excerpt from field book, week 112.

This 'rough' play Celine developed, sometimes at the expense of performance according to her, has had results vis-à-vis the other players. By playing faster, hitting harder than men, she thinks she won the respect, even the admiration of other (male) players. Because, as pointed out by Scott (2014) and Lindemann (2010), the hegemonic masculinity prevailing in disabled sports lead athletes to take a discrediting look at femininity, which is considered as incompatible with sports participation. When their male teammates speak about Club B's players, they often highlight their quasi-masculine fighting spirit upfront. 'Club B's girls on the field... They're not there to make friends, I mean most guys can't compete with them, they run the game!' Salim, club A, excerpt from field book, week 86. So these players' sport identity is full of masculinity. That is how they carve out a place in the masculine world of powerchair football. The studies by Manderson and Peake (2005) and Lindemann (2008, 2010) highlight the hyper virility performed by disabled sportsmen in order to resist the 'feminization' they sometimes are subjected to (Lindemann, 2010). At the same time, these sportswomen do not want to give up their femininity, especially as they claim it is difficult to be seen as 'feminine' when you are a disabled woman: 'It's not easy to be seen as a woman when you're disabled... People don't say 'what a pretty woman', they first think 'she's disabled' or 'she's in a powered wheelchair'. Amelie, excerpt from field book, week 97. In their daily lives, the interviewees' femininity is pushed in the background and sometimes even completely erased behind the stigma of disability. While interacting, their gender identity disappears, masked by their 'disabled person' identity. In sports, as in daily life, it seems to be essential for the interviewees to find alternative ways to preserve a part of their femininity. One of the strategies adopted by sportswomen, which has also been observed in the 'able-bodied' sports sphere (Bohn, 2001; Mercier-Lefèvre, 2005; Richard and Dugas, 2012), is to use clothes as a reminder of femininity. While boys almost systematically adopt sportswear, Celine told us that she does her best to avoid tracksuits, which, she said, look 'too boyish.' To make their femininity visible and emphasize it, players prefer to wear denim pants and urban footwear during training sessions. This dressing strategy is enhanced by the use of jewelry and makeup. The stated objective of this body staging is to respond to the paradoxical situation they find themselves in. They do find a place in this male environment by developing 'masculine' attitudes but at the same time, by performing femininity it makes it possible to go against the 'asexualization' which they are sometimes assigned to.

Just like the hockey players interviewed by Apelmo (2012b), powerchair players strive to find a balance between masculinity and femininity, in order to meet the paradoxical gender injunctions: 'You need to have a sturdy personality [meaning a masculine one], but not too sturdy, because if you're too hard, I mean... It won't do...' Excerpt from the interview with Sonia, 32. This fragile balance requires sportswomen to juggle 
with feminine and masculine norms every day. These observations are reminiscent of Jamieson's research (1995) about the 'double bind': in order to succeed, women need to overcome paradoxical injunctions, that to perform femininity while avoiding appearing weak among others.

Yet, gender is not systematically perceived as 'problematic' by male and female players. According to powerchair football players, one could even, prima facie, be led to call into question gender stereotypes. Indeed the wheelchair, which is a central element in this sport (Richard, 2012), could be considered to deconstruct 'biological' inequalities.

\section{Mixed-sex confrontation, an opportunity to undo gender?}

A dissolution of biological inequalities. Powerchair football, along with ultimate frisbee and korfball, ${ }^{6}$ are the only team sports with mixed-sex matches. However, it is difficult to draw a parallel between the gender construction analysis of these three sports, because of how different the practice patterns are. Indeed, beyond the fact that the former is a sport for disabled people and the other two for 'able-bodied' people, the main difference lies in the way bodies are engaged in motor action. When Guérandel and Beyria (2012) analyze gender social relations at work in ultimate frisbee, they underline that even though the players' bodily involvement is relatively euphemized compared to that in other team sports, the 'biological' differences between men and women lead to motor behaviors that are specific to each player:

During the matches, the techniques used differ depending on the players' gender. Men try things that are supposed to be hard, risky and spectacular while the women's game is simpler and more cautious. [...] Their physical engagement is largely inferior to that of men, who build up their attacks over the whole field in order to create optimal conditions for success of a decisive pass to teammates in the zone.' (Guérandel and Beyria, 2012)

In disabled sport, technology has a game-changing influence. According to Prude and Howe (2013), the bodies' 'cyborgification' is a key determinant of the assessment of the disabled's sporting performance. However, even if the technological hybridization lies at the heart of powerchair football, the players do not meet the 'sporting supercrip' criteria (Howe, 2011) because of their impairment's severity (Prude and Howe, 2013). Still, if the use of electric wheelchairs has not, up to now, allowed players to attain the 'supercrip' status (Howe, 2011), it has an impact on the gender production processes. Indeed, the use of the electric wheelchair erases the biological differences that could 'naturally' exist between men and women (Haraway, 1991).It is not so much the gender that puts the player at a disadvantage, but the disability. Women and men are here on an equal physical 'footing' on the field. According to Loïc, from Club B, this outstanding physical engagement could be an opportunity to challenge gender stereotypes:

'You know, there's always some kind of rivalry between girls and boys. People will say "wow, the girl beat him! She scored a goal! She tricked three guys on the opposing team!" It's not like normal football, in which you can't compare a men's team and a women's team competing at the same level. Here, girls can be better than boys, no problem. It's not about the physical or I don't know what... A woman can come and score three straight goals. And this can also really 
open people's minds. You know what I mean? It can break up stereotypes ... that girls are weaker than boys.' Excerpt from the interview with Loïc, 23.

In the confrontation, women are not disadvantaged by any biological differences. According to Loïc, powerchair football may even become the theater of the domination of women over men. Moreover, the sportswomen we interviewed say they have no problems facing men on the field. They even agree that they derive a certain pleasure from keeping up with men.

'Well you know, playing with guys, I think I like it better. Yeah I do... And why? Well I don't know ... It's motivating! It must be the competitor in me! Playing against guys is motivating. I don't think playing against boys frightens girls. Well, that's just me talking. Maybe it's the more masculine side of football which discourages them. It doesn't scare me off... But I admit I don't know, I can't talk on behalf of others!' Excerpt from the interview with Amelie, 30, from Club B.

Persistent stereotypes. In powerchair football, physiological differences are blurred. This particularity may seem to constitute an opportunity to 'undo gender' but the interviews' analysis proves otherwise. If the players say that 'physically,' women and men are on an equal footing, in their speeches the same athletes, both women and men, establish behavioral and emotional differences between them. There would seem to be a 'nature,' an 'instinct,' male or female, that re-surfaces on the field. Here, disabled sports become the theatre of gender again (Lindemann, 2008). For example, many players told us that women are 'instinctively' rebels:

'Girls have always been very good players. I've noticed that. Their only problem is obeying the coaches. Because they have a hard time understanding why they must do this and that, and only when it's been proven that it works on the field during a match will they do what they're asked [...]. Unlike men, who when they're told to do this and that will say 'yes' and do what they're told. In the case of women, you're gonna have to show them why. Otherwise, they won't do it.' Excerpt from the interview with Damien, 35.

Here, Damien admits that the women on his team have a very good level, but regrets their rebellious nature. He also raises a possible inability for them to read the game, a difficulty to understand the sport that would seem to make them progress slower than their male counterparts. Another 'naturally feminine' feature would be chatting and lacking concentration (Aebischer, 1985). We find this idea in Damien and other players' comments:

'Benoit, Romain and I were watching a game from the sidelines at the end of a training session. On the field, Celine and Amelie were joking among themselves. Romain then talked to me while pointing them out: "Look [he sighs], the problem with girls is they don't last a whole match, they become undisciplined." Romain, excerpt from field book, week 11.

While powered wheelchairs erase physical inequalities, through their speeches the players reintroduce immeasurable differences between men and women. If women are not penalized by physiological differences, they may be by behavioral or even cognitive 
differences. Women also participate in the construction of gender differences, but in another way: according to them, the characteristics specific to women are no longer disadvantageous - on the contrary, they enrich the game.

If you put girls with boys, it will appease and temper them. Because obviously, we do not have the same character and yes... Well anyway, we noticed that in 100 percent masculine teams and at a high level, in the end it's more of a testosterone contest than a real team sport. I'm sorry for my language (laughs). Well, you see what I mean? There...' Excerpt from the interview with Sonia, 32.

For Sonia, the behavioral differences between men and women are real but they are complementary and thus bring some balance into the game. The 'naturally' quiet attitude of women counterbalances men's 'natural' aggressiveness (Manderson and Peake, 2005). Yet, according to the players, playing only with girls would lead to the emergence of tensions:

'We talked with Celine about the possibility of an all-women team, which she has a clear-cut opinion about: "If you only put girls on the field, things will be... tense! [...] There will always be small girl issues, well...". Celine, excerpt from field book, week 36.'

This observation matches in all instances the point made by Guérandel and Beyria (2012) about ultimate frisbee: 'According to the players, women's relational qualities that oppose men's aggressiveness tend to avoid possible conflicts, while men's honesty makes it possible to maintain the group's friendly atmosphere, which is threatened by women's cunning.' (Guérandel and Beyria, 2012).

Gender norms are persistent. Despite the fact that the use of the powerchair erases biological differences, 'natural' differences reappear in the character traits attributed to women or men, which explains the difficulty these women have finding their place in powerchair football. These persistent stereotypes seem to make powerchair football difficult for isolated women, and grouping women within the same club is the solution chosen by the sportswomen we interviewed.

\section{The place of female players in an ultra-masculine environment and in a club with equal representation}

Sonia, who experimented evolving in an exclusively masculine environment when she was preselected to play for the French national team, evokes the machismo that can be prevalent in it, and how difficult it is to be the only woman in a men's sport. She now plays for Club B, which, with three female players, stands as an exception in French powerchair football. This feature, which may seem as the result of happenstance, is actually that of a choice made by the women we interviewed.

High-level access: over-bloated gender norms. Sonia, who is one of the best powerchair football players in France, is actually the first one - and until very recently (2010) the only one - to have been pre-qualified for play with the national team. Nonetheless, she is critical of the way she was treated as a woman at the top level during national team 
gatherings in which she was the only woman. According to her, sexism emerged in several ways during these two gatherings. For example, she explains she was confined to the role of goalkeeper, which was not her usual position and is often considered as less 'interesting' and less technically demanding. Moreover, she says that her non-selection was announced without any explanation, which was not the case for men who were not picked either:

'In the end, what hurt me deeply is the fact that I went to two national team gatherings and only had congratulations. Because even if X [the coach] didn't expect me to perform so well and because additionally, I played goalie and it's really not my position and I still blocked as many shots as S. And then, I'm not saying... I'm not saying I deserved to be on the team or not. But... What I don't understand is that well, I only had congratulations, I wasn't selected and nobody explains to you why you weren't picked. At the same time, there are three or four guys who [...] weren't picked for the national team. But the coach still traveled to the south of the country to talk to them [...] well anyway. [Sonia seems bitter].' Excerpt from the interview with Sonia.

Beyond the fact that she was not told why she had not been selected, it is the difference of treatment during the training sessions that seems to have affected her most. This difference was materialized in the way the coach and some staff members called her:

'People keep saying "no, no, France is not a macho country!" No... Of course not... When you get called like this for a week: "Hey, girl!... Hey, what? Now look... I have a name, just like all these *****! Do you ever say "Hey, boys?" No, you don't! So why do you always call me "the girl"?".' Excerpt from the interview with Sonia, 32.

During the gatherings, the coach systematically called Sonia 'the girl.' Butler (1999) already raised the performative nature of language: a name describes something or someone but is also involved in the construction of this thing or that person. Gender discourses are no exception (Butler, 2009). Calling Sonia 'the girl' imprisons her in a monolithic identity as a 'woman' (Butler, 2007), which is perceived by men as incompatible with the practice of powerchair football, especially at a high level (Lajeunesse, 2008). Using this term calls into question (again) her status of powerchair football player. According to Sonia, establishing oneself in a group of men is a permanent struggle for a woman, when some form of common ground, tacit agreement, seems to prevail in mixed groups.

'But it's sure that between girls... For example, the goalkeeper... Well, if no one plays the position full time we will relay one another. Well, if I've played goalie for 15 minutes another girl will come relay me. We change. But if you're on your own with only guys on the team, well you're going to stay in the goal for half an hour.' Excerpt from the interview with Sonia, 32.

A grouping strategy?. As we already underlined, Club B is the only French club with three women in its ranks. How can this be explained? Club B's players spontaneously invoke chance. These three players would happen to have landed in the same club through a combination of circumstances. 
'Because at the time [when the club was created], there were only three girls. And when the boys left, we only had three girls left. It's mere chance. It could have happened anywhere, but it happened here.' Excerpt from the interview with Damien, 35, from Club B.

However, the theory seems difficult to defend, all the more so as two of Club B's three female players live far from the sports facilities the club uses. It takes them more than an hour to get to practice, when they both could play in a club that plays at an equivalent level less than 30 minutes away from their home. We talked about the reasons for this grouping with them. First of all, the initial recruiting carried out by Club B's former president, Farid, seems to be at the source of this concentration of female players. It seems as though he was particularly attentive to and concerned about the presence of women in the club's membership: 'Our president at the time, Farid, really wanted girls on the team. Not just boys. That's a bit why we [Amelie and Sonia] ended up in this club.' Amelie, excerpt from field book, week 53. Farid is actually at the source of Amelie and Sonia's recruitment. He triggered the club's feminization. And quite rapidly, Club B started to be identified as 'feminine,' an identity that female but also male players do their best to maintain. In this regard the club's logo, which hijacks the Charlie's Angels film poster, is quite telling. Charlie's Angels, 'three talented, tough, attractive women,' illustrate the three players' position in powerchair football:

'We found it funny because initially, there was Amelie, Céline and I who played with either Damien or Benoit. So it was three girls and a guy. And in fact, we were looking for logos and at one point, we told ourselves: "hey, Charlie and his angels, that's fortunate!" But it's true that most people who only know regular football and who discover it [powerchair football] say "but it's mixed!' It's true it surprises a lot of people.' Excerpt from the interview with Sonia, 32.

The use of this logo is reminiscent of the issue of female players who want to stay feminine in order to resist the image of the disabled sportswoman, who is often presented as asexual, while performing well (which is considered incompatible with femininity). Charlie's Angels' heroes seem to be a form of answer to these dilemma: they are the (caricatural) example of 'feminine' women who still physically rival with men, just as in powerchair football.

Club B's players put forward their group's particularity. For Romain, who used to play for Club B, the presence of women at training is largely due to the club's communication:

'It's a choice Club B made. They decided to stand out from the crowd. Because you know I used to belong to Club B so I can tell you about it. As a matter of fact, they based their communication, their project, on the idea that they were the "Charlie's Angel". When the club was created, there was a majority of girls and they told themselves, well, we're going to stand out. In France, it's true there are not a lot of girls. But if you look at the United States, a lot of girls play there.' Excerpt from the interview with Romain, 32, former club B player.

Romain raises the idea that French football's masculine culture permeates powerchair football. On the contrary, in the United States, where soccer is very much identified to the feminine gender (Allaway et al., 2001), the number of high-level, female powerchair football players is very large. ${ }^{8}$ 
'It's totally cultural. And we asked ourselves if we shouldn't start having women's selections, at an international level. But if you do, you lose mixed teams. And it wouldn't be in tune with the spirit in which we created this sport.' Excerpt from the interview with Romain.

For the female players we interviewed, it would actually be unthinkable to play in a club in which there would only be men, even though they claim they do not fear facing men. But being the only woman playing for a team is, according to them, especially complicated, as Sonia explains: 'I like the people in those clubs [with mostly men], no worries. But I think there will never be girls, not even a goalie. Because they don't have the same philosophy.' Excerpt from the interview with Sonia.

\section{Conclusion}

The analysis of powerchair football sheds a light that is complementary to previous studies on the issue of gender construction in disabled sports. We tried to uncover some social mechanisms that are involved in the construction of disabled female athletes' identities who use an electric wheelchair in the sport they are engaged in. We found that the women who play powerchair football are confronted with a dilemma: 'overplaying' a form of masculinity to gain legitimacy in the masculine world of powerchair football, while displaying some femininity to go against the stereotype of the asexual disabled woman. This 'double bind' phenomena women in a leadership position are faced with (Jamieson, 1995) was previously observed by Apelmo (2012a, 2012b) in disabled sport. By describing a stereotyped femininity which does not fit them, the players distance themselves from the image of the 'unathletic girl'. They put in place a set of discursive, behavioral and dressing strategies. This discursive strategy is reinforced by the development of a 'rough' game which seems to legitimize them in physical confrontation. At the same time, the players carefully preserve a form of femininity through a feminine staging of their body.

One of this article's essential differences concerning the knowledge of gender production in disabled sport resides in the fact that powerchair football is played with electric wheelchairs. The player's body is a hybrid body (Haraway, 1991), which blurs the limit between the natural and the artificial, between the human and the machine (Cherney, 1999). The performances of the women we observed show that powerchair football constitutes a space in which the male/female opposition is called into question. Because powered wheelchairs dissipate biological inequalities and gender is not a discriminating factor in performance any more. Indeed, we are witnessing the deconstruction of gender by the 'cyborg' body: in powerchair football, women's body is just as powerful, quick and performing (even more, sometimes) as men's. It truly calls into question men's domination over women. The electric wheelchair's central place constitutes an opportunity to question gender vis-à-vis the body's 'cyborgification'.

Yet we cannot but notice that essentialism re-emerges in the male and female players' discourses. By considering feminine attitudes as incompatible with what makes a 'good sportsperson,' men discredit these sportswomen. Women also take part in the introduction of biological differences because of what they say, by presenting themselves as 'naturally soothing' for men and also admitting they are prone to jealousy. This kind of 
talk directly participates in the marginalization of women. In response to this marginalization, the athletes we observed and interviewed opted for grouping strategies: by getting together in the same club, the best French female players have created a space in which they say they are less affected by sexist remarks and behaviors.

In many aspects, our analysis goes along with the work of researchers who looked into the issue of gender in the sport and disability sphere. These female football players are faced with a paradox because of their triple status as women, athletes and disabled persons (Apelmo, 2012b; Jamieson, 1995). Their answers to this paradox underline the identity construction work they carry out consciously and on a daily basis. Here, the masculine/feminine binary opposition is questioned: far from being deeply incorporated, gender is permanently in play, it is the product of identity 'tinkering'. This does not mean that the gender production mechanisms are superficial or lack substance. On the contrary, what we wish to highlight is that the construction of gender identity is an ongoing process and that sport is a privileged space to question these processes in because it brings the body into play.

\section{Funding}

This research received no specific grant from any funding agency in the public, commercial, or not-for-profit sectors.

\section{Notes}

1. Fédération Française Handisport, 2013/2014 season.

2. Fédération internationale de Powerchair Football Association. Available at: http://fipfa.org (accessed 1 October 2014).

3. Available at: http://www.handisport.org/content/competition/foot_fauteuil.php (accessed 9 March 2009).

4. 87.3\% of men, Fédération Française Handisport, 2013/2014 season.

5. Source: Fédération Française Handisport, 2013/2014 season.

6. We must underline that if men and women are allowed together on the field, only duels between players of the same gender are authorized. It is thus more of a copresence than a real confrontation. Available at: http://www.ikf.org/ (accessed 1 October 2014).

7. Charlie's Angels movie trailer (2000).

8. Two women started for the USA when they won the World Cup in 2011.

\section{References}

Aebischer V (1985) Les femmes et le langage: représentations sociales d'une différence. Paris: P.U.F.

Allaway R, Colin J and Litterer D (2001) The Encyclopedia of American Soccer History. Lanham, MD: Scarecrow Press.

Ancet P (2010) Virilité, identité masculine et handicap. In: Ciccone A (eds) Handicap identité sexuée et vie sexuelle. Paris: Eres, pp.157-170.

Anderson E (2009) Inclusive Masculinity: The Changing Nature of Masculinity. New York: Routledge.

Andrieu B (2008) Devenir hybride. Nancy: Presses Universitaires de Nancy.

Apelmo E (2012a) (Dis)Abled bodies, gender, and citizenship in the Swedish sports movement. Disability \& Society 27(4): 563-574. 
Apelmo E (2012b) Falling in love with a wheelchair: Enabling/disabling technologies. Sport in Society: Cultures, Commerce, Media, Politics 15(3): 399-408.

Azadeh K (2010) Erving Goffman: de la production sociale du genre à l'objectivation sociale des différences biologiques. In: Descoutures V, Varikas E, Chabaud-Rychter D, et al. (eds) Sous les sciences sociales, le genre. Paris: La Découverte, pp.276-288.

Berger P and Luckmann T (1966) The Social Construction of Reality: A Treatise in the Sociology of Knowledge. London: Penguin Books.

Blinde EM and McCallister SG (1999) Women, disability, and sport and physical fitness activity: The intersection of gender and disability dynamics. Research Quarterly for Exercise and Sport 70(3): 303-312.

Bohn C (2001) Le vêtement comme medium. In: Monneyron F (eds) Le vêtement. Paris: L'Harmattan, pp.189-204.

Bohuon A (2008) Sport et bicatégorisation par sexe: test de féminité et ambiguïtés du discours médical. Nouvelles Questions Féministes 27(1): 80-91.

Bourdieu P (2001) Masculine Domination. Stanford, CA: Stanford University Press.

Brittain I (2008) The evolution of the Paralympic Games. In: Cashman R and Dracy S (eds) Benchmark Games: The Sydney 2000 Paralympics Games. Sydney, NSW, Australia: Walla Walla, pp.19-34.

Butler J (1988) Performative acts and gender constitution. An essay in phenomenology and feminist theory. Theatre Journal 40(4): 519-531.

Butler J (1999) Gender Trouble: Feminism and the Subversion of Identity. New York and London: Routledge.

Butler J (2007) Le récit de soi. Paris: P.U.F.

Butler J (2009) Ces corps qui comptent. De la matérialité et des limites discursives du 'sexe'. Paris: Editions Amsterdam.

Cherney JL (1999) Deaf culture and the cochlear implant debate: Cyborg politics and the identity of people with disability. Argumentation and Advocacy 36(1): 22-34.

Connell RW (2000) The Men and the Boys. Cambridge: Polity Press.

De Beauvoir S (1949) Le deuxième sexe. Paris: Gallimard.

DePauw K (1999) Girls and women with disability in sport. Journal of Physical Education, Recreation and Dance 70(4): 50-52.

Dufour P (2014) Au-delà du handicap: de l'expression par les mots à l'expression par l'espace. SociologieS, Théories et recherches. Available at: http://sociologies.revues.org/4607 (accessed 12 September 2014).

Duret P (2009) Sociologie de la compétition. Paris: Armand Colin.

Gilbert K and Schantz O (2008) The Paralympic Games: Empowerment or Sideshow? Maidenhead: Meyer \& Meyer Sport.

Glesne C (2011) Becoming Qualitative Researchers. Boston, MA: Pearson.

Goffman E (1975) Stigmate. Les usages sociaux des handicaps. Paris: Les Editions de Minuit.

Goffman E (1977a) La ritualisation de la féminité. Actes de la recherche en sciences sociales 14: $38-49$.

Goffman E (1977b) The arrangement between the sexes. Theory and Society 4(3): 301-331.

Goffman E (1988) Les moments et leurs hommes. Paris: Le Seuil.

Groenen H (2005) La pratique du judo féminin en France et en Angleterre de l'entre-deux-guerres au début des années 1970: entre tradition et sportivisation, entre tutelle masculine et émancipation. In: Terret T (eds) Sport et genre. Paris: L'Harmattan, pp.223-242.

Guérandel C and Beyria F (2012) Le sport, lieu de questionnement des rapports sociaux de sexe? L'exemple d'une pratique collective mixte en compétition. SociologieS, Théories et recherches. Available at: http://sociologies.revues.org/3974 (accessed 12 September 2014). 
Guérandel C and Mennesson C (2007) Gender construction in judo interactions. International Review for the Sociology of Sport 42(2): 167-186.

Guthrie SR and Castelnuovo S (2001) Disability management among women with physical impairments: The contribution of physical activity. Sociology of Sport Journal 18: 5-12.

Guttmann L (1976) Textbook of Sport for the Disabled. Aylesbury: HM \& M.

Handisport (2012) L'événement: mondial foot-fauteuil Paris 2011. Revue officielle de la Fédération Française Handisport 146: 14-21.

Haraway DJ (1991) Simians, Cyborgs, and Women: The Reinvention of Nature. London: Routledge.

Hardin M (2007) 'I consider myself an empowered woman': The interaction of sport, gender and disability in the lives of wheelchair basketball players. Women in Sport and Physical Activity Journal 16(1): 39-52.

Hardin M and Hardin B (2005) Performance or participation pluralism or hegemony? Images of disability \& gender in sports n spokes magazine. Disability Studies Quarterly 25(4). Available at: http://dsq-sds.org/article/view/606/783 (accessed 12 September 2014).

Hargreaves J (2006) Les approches féministes du sport. In: Ohl F (eds) Sociologie du sport. Perspectives internationales et mondialisation. Paris: Presses universitaires de France, pp.109-130.

Hargreaves JA and Hardin B (2009) Women wheelchair athletes: Competing against media stereotypes. Disability Studies Quarterly 29(2). Available at: http://www.dsq-sds.org/article/ view/920/1095 (accessed 12 September 2014).

Hendey N and Pascall G (1998) Independent living, violence and the threat of violence. Disability \& Society 13(3): 415-427.

Highlen PS and Finley HC (1996) Doing qualitative analysis. In: Leong FTL and Austin JT (eds) The Psychology Research Handbook. Thousand Oaks, CA: SAGE, pp.177-192.

Hodkings SL and Baility S (2009) The discursive construction and invalidation of disability. In: Marshall C, Kendall E, Banks M, et al. (eds) Disabilities: Insights from across Fields and around the World. London: Praeger, pp.213-229.

Howe D (2011) Cyborg and supercrip: The Paralympics technology and the (dis)empowerment of disabled athletes. Sociology 45(5): 868-882.

Inckle K (2014) A lame argument: Profoundly disabled embodiment as critical gender politics. Disability \& Society 29(3): 388-401.

Jamieson KH (1995) Beyond the Double Bind: Women and the Leadership. New York: Oxford University Press.

Joncheray H, Level M and Richard R (2014) Identity socialization and construction within the French national rugby union women's team. International Review for the Sociology of Sport. Available at: http://irs.sagepub.com/content/early/2014/02/11/1012690213517108 (accessed 12 September 2014).

Kafer A (2003) Compulsory bodies: Reflections on heterosexuality and ablebodiedness. Journal of Women's History 15(3): 77-89.

Korff-Sausse S (2011) Des gender studies aux disability studies: repenser les catégories. Champ Psy, L'esprit du Temps 58: 37-53.

Kumari Campbell F (2009) Contours of Ableism: The Production of Disability and Abledness. New York: Palgrave Macmillan.

Lajeunesse LS (2008) L'épreuve de la masculinité. Béziers: H\&O Editions.

Lindemann K (2010) Masculinity, disability and acces-ability: Ethnography as alternative practice in the study of disabled sexualities. Southern Communication Journal 75(4): 433-451.

Lindemann K and Cherney J (2008) Communication of and through 'Murderball': Masculinity and disability in wheelchair rugby. Western Journal of Communication 72(2): 107-125. 
Louveau C (1986) Talons aiguilles et crampons alu. Les femmes dans les sports de tradition masculine. Paris: INSEP.

McKay J and Laberge S (2006) Sport et masculinités. Clio: Histoire, Femmes et Sociétés 23: 239-267.

McRuer R (2006) Crip Theory: Cultural Signs of Queerness and Disability. New York: New York University Press.

Manderson L and Peake S (2005) Men in motion: Disability and the performance of masculinity. In: Sandhal C and Auslander P (eds) Bodies in Communication: Disability and Performance. Anna Arbor, MI: University of Michigan Press, pp.230-242.

Marcellini A (2005) Des vies en fauteuil. Usage du sport dans les processus de déstigmatisation et d'intégration sociale. Paris: CTNERHI.

Mead M (1963) Coming of Age in Samoa: A Psychological Study of Primitive Youth for Western Civilisation. New York: William Morrow \& Company.

Mennesson C (2005) Etre une femme dans le monde des hommes. Socialisation sportive et construction du genre. Paris: L'Harmattan.

Mercier-Lefèvre B (2005) Pratique sportives et mise en scène du genre: Entre conservation, lissage et reformulation. L'exemple de la jupe chez les joueuses de tennis. In: Terret T, Liotard P, Saint-Martin J, et al. (eds) Sport et genre, vol. 1. Paris: L'Harmattan, pp.369-379.

Messner MA (1990) When bodies are weapons: Masculinity and violence in sport. International Review for the Sociology of Sport 25(3): 203-220.

Messner MA (2007) Out of Play. Critical Essays on Gender and Sport. Albany, NY: State University of New York Press.

Oakley A (1972) Sex, Gender and Society. London: Temple Smith.

Oliver M (1990) The Politics of Disablement. London: Palgrave Macmillan.

Oliver M (2013) The social model of disability: Thirty years on. Disability \& Society 28(7): 1024 1026.

Patton MQ (2002) Qualitative Research and Evaluation Methods. Thousand Oaks, CA: SAGE.

Pike E (2007) Revisiting the 'Physical Activity, Sexual Health, Teenage Identity Construction Nexus'. International Review for the Sociology of Sport 42(3): 309-319.

Porter JI (1997) Forward to the body and the physical difference: Discourses of disability. In: Mitchell DT and Synder SL (eds) The Body and the Physical Difference: Discourses of Disability. Ann Arbor, MI: University of Michigan Press, pp. xiii-xiv.-

Prude DE and Howe D (2013) Who's in and who's out? Legitimate bodies within the Paralympics games. Sociology of Sport Journal 30: 24-40.

Richard R (2012) L'expérience sportive du corps en situation de handicap: vers une phénoménologie du fauteuil roulant. STAPS: The International Journal of Sport Science and Physical Education 98: 127-142.

Richard R (2014a) La globalisation d'une pratique handisport. L'exemple de l'internationalisation du foot-fauteuil et ses réceptions locales. In: Sudre D and Genty M (eds) Le sport, diffusion globale \& pratiques locales. Paris: L'Harmattan, pp.129-146.

Richard R (2014b) Vers une nouvelle « capabilité » sportive: l'émergence du foot-fauteuil. Jurisport 140: 28-29.

Richard R and Dugas E (2012) Le genre en jeu. De la construction du genre dans les interactions en tennis de table. SociologieS, Théories et recherches. Available at: http://sociologies.revues. org/3969 (accessed 12 September 2014).

Ruffié S and Ferez S (2013) Corps, Sport, Handicaps: L'institutionnalisation du mouvement handisport (1954-2008). Paris: Tétraèdre.

Sandelowski M (2000) Whatever happened to qualitative description? Research in Nursing and Health 23: 334-340. 
Schell LA and Rodriguez S (2001) Subverting bodies/ambivalent representations: Media analysis of Paralympian, Hope Lewellen. Sociology of Sport Journal 18(1): 127-135.

Scott JA (2014) Illuminate the vulnerability of hegemonic masculinity through a performance: Analysis of physically disabled men's personal narratives. Disability Studies Quarterly 34(1). Available at: http://dsq-sds.org/article/view/3570/3526 (accessed 12 September 2014).

Shakespeare T and Watson N (2001) The social model of disability: An outdated ideology? Research in Social Science and Disability 2: 9-28.

Sherry M (2004) Overlaps and contradictions between queer theory and disability studies. Disability \& Society 19(7): 769-783.

Sherry M (2014) Emerging perspectives on disability studies; Foundations of disability studies. Disability \& Society 29(10): 1683-1687.

Strauss A and Corbin J (1990) Basics of Qualitative Research: Grounded Theory Procedures and Techniques. Newbury Park, CA: SAGE.

Watson N and Woods B (2008) A social and technological history of the wheelchair. In: Lofaso F and Lepoutre FX (eds) Le fauteuil roulant. Paris: Editions Frison-Roche, pp.9-20.

Wenner L and Jackson S (2009) Sport, Beer, and Gender: Promotional Culture and Contemporary Social Life. Zurich: Peter Lang Publishers.

Wittig M (1978) The Straight Mind. New York: MLA; Feminist Issues 1(1): 103-111.

Zitzelsberger H (2005) (In)visibility: Accounts of embodiment of women with physical disabilities and differences. Disability \& Society 20(4): 389-403. 